\title{
AGRADECIMENTO DA ENFERMEIRA DO ANO
}

\author{
Haydée Guanais Dourado
}

A Divisão Hospitalar da Johnson e Johnson, aqui representada pelo seu Gerente, Sr. Mário Dias Moraes e pela Sr. ${ }^{a}$ Clarice Della Torre Ferrarini, agradeço o Premio Enfermeira do Ano que hoje recebo. Meus aplausos a Johnson e Johnson, empresa multinacional, à sua deliberação de prestar honra aos enfermeiros, estes que, no mundo inteiro contribuem para a saúde dos povos. Meus agradecimentos aos ilustres membros do Juri, dentre eles a Prof. ${ }^{a}$ Maria Rosa Sousa Pinheiro que dedicaram seu tempo valioso ao exame do curso de minha vida, somando honra a meus pequenos títulos.

Encontrei na profissão de enfermagem as condições para dar expressão à minha vida. É no grupo do pessoal de enfermagem que tenho encontrado um lugar para contribuir em meu país.

Agradeço aos que me têm como parte do grupo.

Aos do Norte - Acre, Amazonas e Pará. Daí me veio uma dimensão maior de ternura pelos meus semelhantes. A etnia dos índios que prevalece nessa região despertou ressonância, porque também tenho ascendência indígena.

Aos do Sudeste. Minas, Espírito Santo, Rio de Janeiro, Guanabara e São Paulo. Tenho aprendido e continuo a aprender com as colegas dessa Região.

Aos do Sul. Uma experiência marcante, com responsabilidade de deliberar. no trabalho de verificação de Escola, foi gratificante em crescimento profissional.

Aos do Centro-Oeste. Aí vivo e trabalho, em convívio profissinal que se enriquece cada dia.

Finalmente o Nordeste. Aqui nasci. Daqui são e foram meu pai, minha mãe, minhas irmãs e irmãos e seus descendentes. Aqui cresci e fiz duas opções de vida principais, - pela enfermagem e por Cristo. Dele vêm todos os dons. Todo o dom perfeito vem de Deus. A Ele seja dada toda a glória. 